\title{
Factors Affecting the English Language Preparedness of College Freshman Students
}

\author{
Fengyi Ma \\ Office of Foreign Languages, Guilin Medical University, China
}

\begin{abstract}
This study determined the factor that affects the level of preparedness in the English language of the College of Education (COED) freshman students majoring in Elementary Education. Eighty (80) students were chosen as the participants of this study. A survey questionnaire was used to explore the students' opinions by considering six factors that may have affected their preparedness in English: Prior knowledge of the second language of learners, students' motivation, learning styles of students, instructional methods of teachers, classroom setting, and school amenities. The findings revealed that the classroom environment and the classroom and school facilities affected their preparedness. Moreover, the teacher's availability of learning materials, teaching method, and student's motivation were also additional factors that affected them. The results imply that the government should do its best to provide these students with facilities and more learning materials. As a result, the English I course teachers should consider all these when teaching English to enhance their preparedness.
\end{abstract}

Index Terms - level of preparedness, English Language, Second Language

\section{INTRODUCTION}

English is considered the universal language. It functions as an instrument for international reach and local identities. In meeting the demands of time and thoroughly preparing them for globalization, learners need to obtain greater linguistic competence levels. According to Mijares (2009), the English language is a compulsory subject beginning in second grade, continuing through postsecondary education as students must become proficient at using the language. The English language class is the central location where students learn the English language; it is seldom incorporated into other courses or within their homes. That is why the education system promotes enhancing the learners' English language proficiency.

The results of the National Achievement Test given by the Department of Education (DepEd) in the Philippines showed low English language performance among high school students. The English proficiency level of students is deteriorating. Andrew King of IDP (International Development Program), the Education and country director for the Philippines, was disappointed in the International English Language Testing System (IELTS) of 2009 when the Philippines came second with a score of 6.69. Furthermore, the deputy presidential spokesperson, Lorelie Fajardo, acknowledged that there was an issue. Most elementary and secondary education teachers have average English proficiency ratings of 50 percent for elementary teachers and 67 percent for secondary teachers. A current literacy test results reported that the Philippines is no longer Asia's top English-speaking nation. This has had a disturbing effect on the job-providing sectors in and out of the state and is starting to push the Department of Education to step up the initiative to provide a school system that will enhance the knowledge of the English language for learners. Nevertheless, school programs and initiatives are not sufficient to encourage English proficiency among Filipino students.

Increasing accessibility to students who are not prepared for college courses, several academic institutions offer higher education opportunities. Bailey (2009) advocated for evaluations to address educational readiness to effectively recognize underequipped university students' concerns. Preparedness should also involve the ability to adapt to environmental changes successfully. He explained how students compensate for their weaknesses and adapt to their environmental challenges.

One of the essential times for developing language ability and fundamental skills would be during early school. Speaking abilities gained and learned throughout early schools are essential in both development and continuity. Hence to develop language ability throughout early schools, it is necessary to use efficient and reliable teaching methods.

In this context, the researcher had to examine the factors affecting the College of Teacher Education freshman students' readiness to use the English language. Lately, several studies have been conducted to determine the relevance of these factors in education. Boylan (2009) claimed that non-cognitive (i.e., affective \& personal elements with cognitive factors) are coupled to create personalized approaches for unprepared students. Also, Boylan (2009) indicated that individual factors could affect school efficiencies, such as childcare obligations and language barriers.

This study gathered data and knowledge on what steps could be taken by English teachers and curriculum designers to help students develop their English acquisition and help them improve their speaking ability. Also, students, English teachers, and curriculum designers are expected to benefit from this study since it will offer insights about how teachers could further develop English language literacy and university students' necessary linguistic skills. 


\section{RESEARCH METHODOLOGY}

The qualitative research methodology was used to determine how many variables have affected the degree or readiness of college students in English. The Data in this study were collected from 80 freshman students majoring in Elementary Education at Tarlac State University, Tarlac City, Philippines. All participants were enrolled at the University at the time of the study. Students also provided information about their previous high school education. Thirty-eight students reported that they came from public high schools, while the remaining 42 participants stated that they graduated from private high schools. To use the students' recorded responses for data analysis and to conduct a set of questionnaires, informed written consent was obtained. For the research completion, participants allowed the researcher to use their responses.

Moreover, the questionnaire developed by Bennui (2009) entitled "Study on First-Year Students Perceptions Concerning Causes of Their Poor Performance in the English II Course" was used in this study.

This study's data emerged from an analysis of questionnaires that were individually conducted with 80 freshman students in two sessions under two different instructors. It lasted for about 15 minutes, and the results were transcribed into tables. Participants were asked about their stand on the given factors such as their language prior knowledge (English background, previous grade); students' motivation (self-motivation, motivation given by parents and teachers, opportunities for practicing speaking and writing); students' learning strategies (taking notes, talking to native speakers, listening to songs, reading books); teacher's teaching method (unclear pronunciation, too fast in speaking); classroom environment (too noisy, unapproachable classmates); and, classroom facilities (lack of materials) if these are significantly affecting their performance inside the classroom. The study aimed to answer the central research question, which is the factors affecting the level of preparedness of COEd freshman students majoring in the English language.

\section{RESULTS AND DISCUSSION}

As reported, $52.5 \%$ of the students were from private schools, while $47.5 \%$ were from public schools. Most of the students were, therefore, enrolled in a private institution. According to Piras (1998), Growing interest in high-cost private colleges has led to public education's falling standard. Parents who are willing to assume the expense of a private school tend to transfer their kids from the public to private institutions, thinking they can probably get a better education in this manner.

TABLE 1

Present The Students' Second Language Prior Knowledge As A Factor AfFecting The LeVel Of PreParedness Of COED FRESHMAN STUDENTS

\begin{tabular}{|c|c|c|c|c|c|c|c|c|}
\hline \multirow[t]{2}{*}{ Factor } & \multicolumn{4}{|c|}{ Level of Agreement } & \multicolumn{4}{|c|}{ Level of Disagreement } \\
\hline & $P u b$ & $R$ & Priv & $R$ & $P u b$ & $R$ & Priv & $R$ \\
\hline \multicolumn{9}{|l|}{ Students' Second Language Prior Knowledge } \\
\hline $\begin{array}{l}\text { My previous grades in my English subjects } \\
\text { were poor, so I don't think I can now improve } \\
\text { on it. }\end{array}$ & 8 & 3 & 8 & 3 & 30 & 1 & 34 & 1 \\
\hline $\begin{array}{l}\text { My English background on vocabulary, } \\
\text { grammar, and spelling is quite poor. }\end{array}$ & 10 & 2 & 14 & 2 & 28 & 2 & 28 & 2 \\
\hline $\begin{array}{l}\text { I had previously learnt reading-writing rather } \\
\text { than listening-speaking skills. }\end{array}$ & 18 & 1 & 24 & 1 & 20 & 3 & 18 & 3 \\
\hline
\end{tabular}

Table 1 indicated that both students from private and public high schools agreed that they had learned readingwriting first rather than listening-speaking skills. Writing and reading have long been known as practices that are interconnected. In addition to listening and speaking, teachers have viewed them as essential English elements (Petty, 1983). Students from public and private disagreed that their previous grades in English were low, so they don't think they can improve it; indicating that how well a student performs in the English language will depend on his or her perceptions to that particular language. Misati (2009) believes that English is the most difficult language to learn; students may be discouraged from working hard, thus ending up with low grades. However, their positive perception of English as one of the most important languages will motivate them to work hard and improve their achievement.

TABLE 2

Present The Students' Motivation As A FACTOR AfFecting The LeVEl Of Preparedness Of COED Freshman Students

\begin{tabular}{|c|c|c|c|c|c|c|c|c|}
\hline 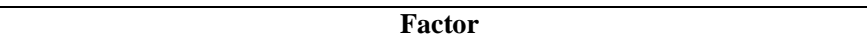 & \multicolumn{4}{|c|}{ Level of Agreement } & \multicolumn{4}{|c|}{ Level of Disagreement } \\
\hline Students 'Motivation & Pub & $\mathrm{R}$ & Priv & $\mathrm{R}$ & Pub & $\mathrm{R}$ & Priv & $\mathrm{R}$ \\
\hline $\begin{array}{l}\text { 2.1 I do not have opportunity to practice speaking and writing in } \\
\text { English. }\end{array}$ & 9 & 4 & 3 & 5.5 & 29 & 3 & 39 & 1.5 \\
\hline 2.2 I am not interested in learning English. & 5 & 5 & 6 & 4 & 33 & 2 & 36 & 3 \\
\hline 2.3 I think learning English is not important, so I am not self- motivated. & 3 & 6 & 3 & 5.5 & 35 & 1 & 39 & 1.5 \\
\hline 2.4 My classmates rarely motivate me to practice my English speaking skill. & 15 & 3 & 25 & 1 & 23 & 4 & 17 & 6 \\
\hline $2.5 \mathrm{My}$ parents never encourage me to speak English at home. & 17 & 2 & 8 & 3 & 21 & 5 & 34 & 4 \\
\hline 2.6 My close friends tease me whenever I speak English to them. & 18 & 1 & 12 & 2 & 20 & 6 & 30 & 5 \\
\hline
\end{tabular}


In every classroom, some students have problems when it comes to speaking in front of the class. Table 2 portrayed that the public schools' students indicated that 'teasing' affects their low motivation. Students report that their peers make fun of how they speak English. The discomfort experienced by these students often has to do with bad experiences, which include 'teasing'.

Students from private schools have the highest effect on the factor "My classmates rarely motivate me to practice my English-speaking skill." Motivation and attitude are a critical key to the successful acquisition of a second language and are connected to second language acquisition. Students were found to have a conviction from this research about the essence of motivation affecting their accomplishment. The motivation was a significant factor in the acquisition of second language performance and an individual who has higher motivation would like to learn a language, enjoy language-learning, and attempt to learn the target language. (Budden, 2003).

TABLE 3

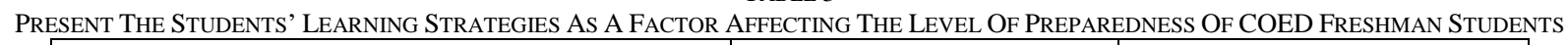

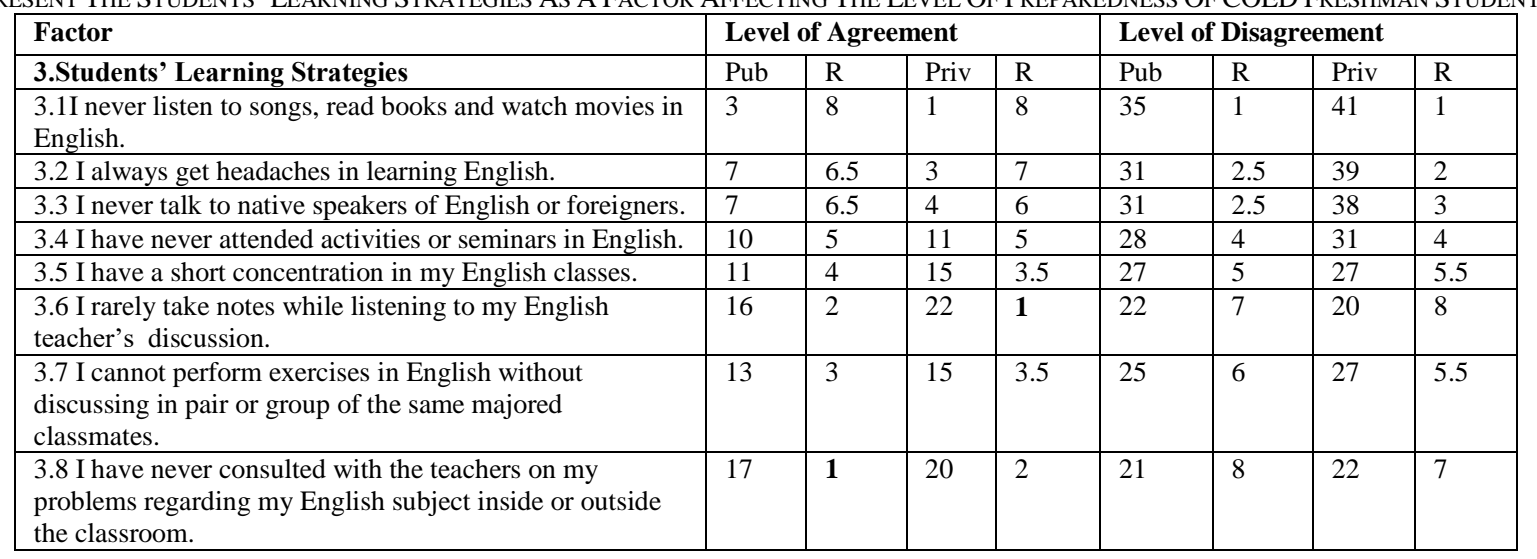

In Table 3, students from public schools stated that they never consulted with their teachers regarding their English subjects. This instance shows no communication between the students and the teacher, affecting students' motivation to learn. Communication inside the classroom includes many things, such as sharing information, feelings, thoughts, influences, and problems students encounter. It is essential because it functions as a tool for contact, transfer of ideas, influences, and development. Every opportunity to communicate offers a chance for personal development.

Both students from private and public high schools disagreed that they never listened to English songs, books, and movies. This means that materials like these had greatly affected their learning strategies in learning the Language. Because music and songs are essential tools for facilitating language learners' motivations and influencing their motivation, using music and songs could change a mood or create an atmosphere conducive to learning (Murphey, 2002). Abbott, Lauter, \& Dalton (2007) also affirmed that using songs or music in English fields may contribute to language acquisition in several dimensions. Also, many researchers have found that films draw students' attention and can have a positive effect on their motivation to learn. Films offer students a great opportunity to acquire context knowledge to incorporate their knowledge of a story or concept. Film features could help students relate to new data they may not have had a context and apply their new concepts, photos, and feelings to the text at hand and this may be fascinating for students and could positively affect their learning motivation.

TABLE 4

Present The Teachers' Teaching Method As A Factor AFFeCting The Level Of Preparedness Of COED Freshman Students

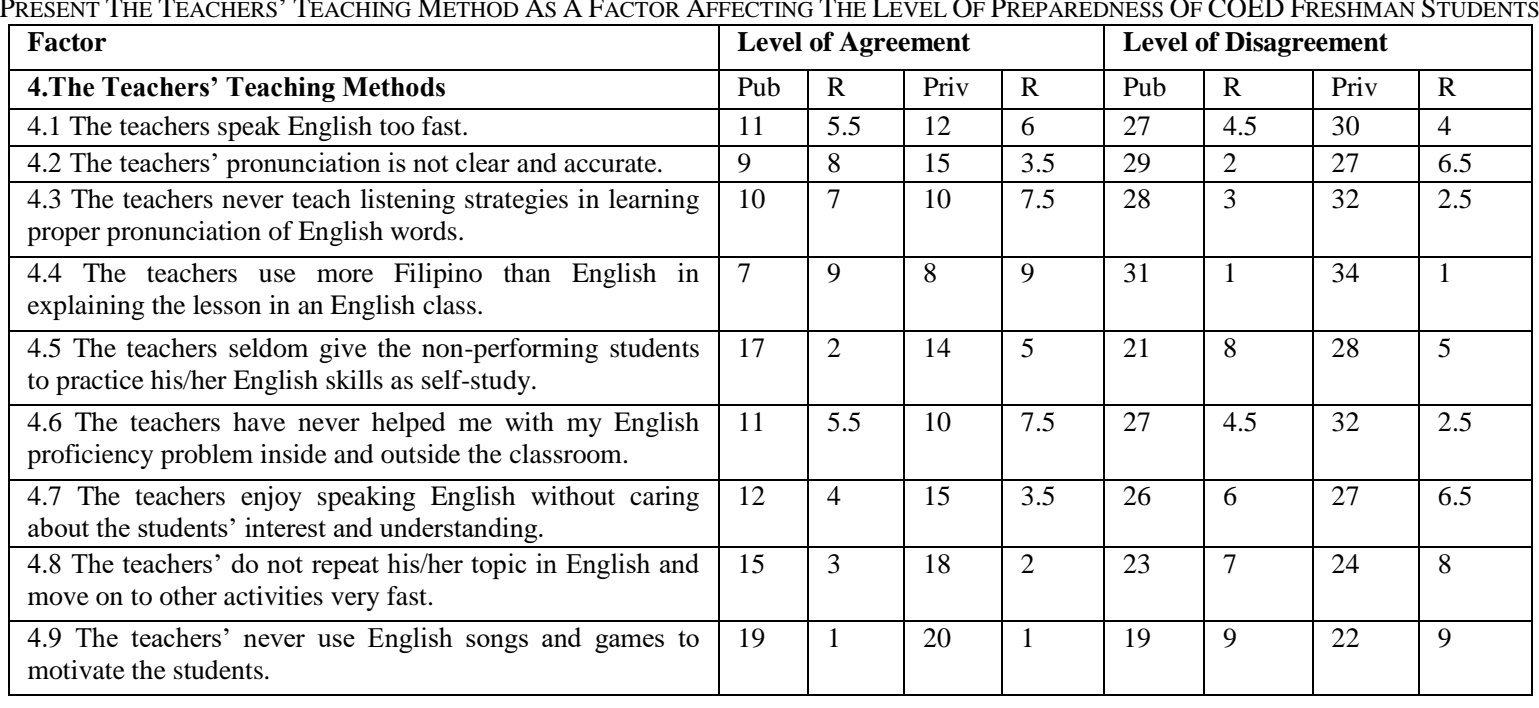


The result from Table 4 presents that students from public schools showed that the teachers never use English songs and games to motivate students as their number one factor in the Teachers' Teaching Methods.

On the other side, all students disagreed that the teacher's use of the Filipino language in explaining the lesson affects their learning and understanding of the lesson. While it may seem detrimental to make English language learners depend on their mother tongue when they have trouble voicing and recognizing a concept in English, this could help increase English literacy by using their first language awareness. Students unable to speak English or struggling with a particular element of literacy have the option to use strategies they have studied in their mother tongue (Haneda, 2006). When writing or speaking in their mother tongue, English language learners have skills and talents, and teachers may then recognize these attributes and then incorporate them into the program for English education. To recognize individual skills and educate learners on how and when to use them while interacting in English, teachers also suggest that teachers collaborate with English language learners.

Hanushek (1999) recommends that in teaching, the teacher must have views about the students' desires, learning methods, and the best method of motivating them. The teacher will determine how to offer lessons and exercises in a meaningful manner in light of his experience and how to plan and conduct an exciting and well-organized course development.

TABLE 5

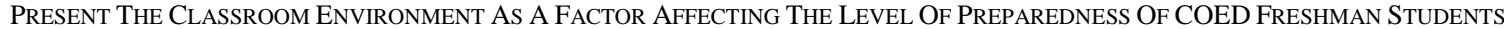

\begin{tabular}{|c|c|c|c|c|c|c|c|c|}
\hline Factor & \multicolumn{4}{|c|}{ Level of Agreement } & \multicolumn{4}{|c|}{ Level of Disagreement } \\
\hline \multicolumn{9}{|l|}{ 5. Classroom Environment } \\
\hline & Pub & $\mathrm{R}$ & Priv & $\mathrm{R}$ & Pub & $\mathrm{R}$ & Priv & $\mathrm{R}$ \\
\hline $\begin{array}{l}5.1 \text { I am too shy, worried, and unprepared to answer the teachers' } \\
\text { questions after his/her discussion of the topic in English among other } \\
\text { classmates with different majors. }\end{array}$ & 11 & 4 & 27 & 1 & 27 & 1 & 15 & 4 \\
\hline 5.2 Other students laugh at me if I pronounce a word incorrectly. & 16 & 2 & 22 & 3 & 22 & 3 & 20 & 2 \\
\hline $\begin{array}{l}\text { 5.3 Some students talk or make noises while the teachers are } \\
\text { explaining his/her lesson. }\end{array}$ & 22 & 1 & 23 & 2 & 16 & 4 & 19 & 3 \\
\hline $\begin{array}{l}\text { 5.4My classmates create a threatening atmosphere during class } \\
\text { recitation using the English language. }\end{array}$ & 12 & 3 & 13 & 4 & 26 & 2 & 29 & 1 \\
\hline
\end{tabular}

Students from public schools considered "Some students talk or make noises while the teachers are explaining his/her lesson." as the highest factor in the classroom environment in contrast with the students from a private school who considered. "I am too shy, worried, and unprepared to answer the teachers' as the factor that has the highest effect questions after his/her discussion of the topic in English among other classmates with different majors." It is common to find learners not so confident in all countries where English is the second or third language. The fundamental explanation for the shyness is the immense distance they experience when talking to students who have a very strong command of the English language or listening to their social circle talking proficiently. This gap between what could be achieved by the student may cause one to do badly in classes. This bad performance then reinforces the perception that English learners are not quite as intelligent as their classmates who speak English.

TABLE 6

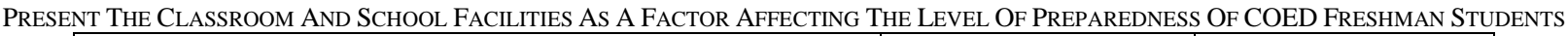

\begin{tabular}{|c|c|c|c|c|c|c|c|c|}
\hline Factor & \multicolumn{4}{|c|}{ Level of Agreement } & \multicolumn{4}{|c|}{ Level of Disagreement } \\
\hline 6.Classroom and School Facilities & Pub & $\mathrm{R}$ & Priv & $\mathrm{R}$ & Pub & $\mathrm{R}$ & Priv & $\mathrm{R}$ \\
\hline 6.1 The classroom is very noisy. & 13 & 3 & 18 & 3 & 25 & 2 & 24 & 2 \\
\hline 6.2 The classroom size is too large and crowded. & 7 & 4 & 14 & 4 & 31 & 1 & 28 & 1 \\
\hline $\begin{array}{l}6.3 \text { Our school library is not updated with new materials in learning } \\
\text { the English language. }\end{array}$ & 14 & 2 & 19 & 1.5 & 24 & 3 & 23 & 3.5 \\
\hline 6.4 No available reading materials in English inside the classroom. & 22 & 1 & 19 & 1.5 & 16 & 4 & 23 & 3.5 \\
\hline
\end{tabular}

Found in Table 6 is the agreement of students from private and public high schools in the non-availability of materials as the first factor in their preparedness level. Both of them also disagreed that a large classroom has something to do with their performance.

Many educators believe that smaller classes allow more time and attention to each student in terms of class size. Class size is an important factor in school-related issues. Smaller classes allow more time for instruction and require less time for discipline while extremely large classes are also inappropriate (more than 60 students per teacher), as they are counterproductive to learning. Howley, Strange, and Bickel (2000) also researched school size and school performance in impoverished communities where they gathered evidence that smaller schools enhance achievement. In contrast, the evidence from their study affirms that small is generally better.

The analysis indicated that three main factors are significant in the students' level of preparedness.

The first factor that the students consider was the non-availability of materials and facilities in English inside the classroom coming from the respondents from the public school.

Some studies conclude that this factor impacts performance when students lack materials and proper facilities needed for learning. Harbison and Hanushek's (1992) detailed case studies give specific evidence that educational facilities' minimum basic standard is critical for achievement performance. Similarly, Husen (2001) says that access to 
educational material has a positive effect on performance. These arguments reinforce the current study findings that textbooks and availability of teaching and learning resources influence students' achievement. These researches highlight the significance of teaching materials and libraries as important components that improve elementary and high school performance. Classroom materials should be designed to provide numerous forms of representation, participation, and communication for students. Selecting resources which will enable learners to study and develop their language skills is equally critical.

The second factor was language anxiety under the classroom environment was chosen by 27 respondents from the private group. They indicated that they are too shy to speak and worried that they might commit mistakes while reciting or speaking during classroom discussions. As learners with less language ability join English learning classes, they have much more to be worried about; raising the probability that insecurity will impact the learning experience. As Horwitz (2001) stated, anxiety is a complex issue and might make the usual performance of people particularly challenging, especially in a multicultural classroom. Anxiety in the English language is a dynamic problem that may contribute to several factors involved in learning environments.

In the lighter shade, the students disagreed that English is not important. Knowing that they are majoring in Elementary Education, they all believe that learning the language is significant and, therefore, they can improve their performance and continue building their knowledge. Since English has been the most popular language used anywhere, English's value could not be overlooked and avoided. The results also stated that learners were more inspired to learn English.

The third factor that the respondents consider is the contact of songs, books, and movies in the English language that the teacher seldom or never at all present inside the classroom to motivate learning. The benefit of incorporating songs and books in the classrooms would be that singing and reading literature is probably one of the activities that produce the highest motivation and is a fun and enjoyable method to learning languages. Komenský (2008) also requested that the environment of endless fun and imagination be maintained. He claimed that to prevent boredom, which is considered the teaching poison, "cheerful atmosphere is required." Music and beautiful forms of literature certainly can sustain an easy educational environment. In school, songs will provide a fun break from routine, and they serve a helpful role in language instruction. Books, on the other hand, are a good source of information that has infinite advantages. It takes us through various worlds and cultures. Also, it helps us to learn about new technologies and literature. It allows speaking languages fluently and to communicate spontaneously. The role of radio and television are also very important in learning the English language because by listening and watching television, students will be used to hearing pronunciation and speaking from a foreign language. In listening or watching, we learn to understand what the people said and increase vocabulary. Exposure to mainstream media often affects the attitude towards the English language. Many who watch English Television shows get a language mindset that is more beneficial than those that do not.

As a research survey, this research assessed the students' views about the variables that could influence their level of English language readiness to provide effective suggestions to other potential solutions to their learning challenges.

\section{CONCLUSION}

Research shows the three main factors that affect the preparedness of the students. These factors need to be supported and given action to prepare students and succeed in their college education. Schools should address these needs by providing educational materials to help build and support students' abilities and ensure their capacity to meet the University's expectations. The findings indicate the difference in the factor affecting the students coming from private and public high schools. Public high school students revealed that the non-availability of materials is an essential factor for language proficiency. The main philosophy behind this is that students from private schools have more access to the facilities that can help them improve their knowledge of the language. The results imply that the government should do its best to provide these students with facilities and more materials.

The third factor that both students from private and public schools have agreed upon is the effect of reading books, listening to music, and watching movies in English in their language enhancement. The primary reason for this is that these materials are important sources for developing the students' proficiency and exposing them to a foreign language, which is sometimes missing in society.

Also, providing necessary assistance to help all students meet college readiness standards providing them support and information are needed. Awareness of these factors may help educators reduce obstacles in learning and preparing their students in the English language and creating more positive experiences and better outcomes.

The research into how these factors affect the preparedness of COED freshman students majoring in Elementary Education could benefit future research. It may help understand the different needs of students and how the government, schools, and teachers help the academic underprepared college students compensate for low performance.

This study reported findings on the preparedness of 80 COED freshman students majoring in Elementary Education. Their perceptions and opinions were willingly expressed and resulted in three major factors. Therefore, this study may serve as a pilot study and be expanded to multiple locations with larger students. Additionally, consideration should be given to how teachers transmit their knowledge to their students. Further research may explore the other factors that were not considered. 


\section{REFERENCES}

[1] Mijares. (2009). Facilitating second language listening comprehension: Acquiring successful strategies. ELT Journal. 53 (3) $168-176$.

[2] Bailey. (2009). Preparedness of Chinese students for American culture and communicating in English. Journal of International Students, 3(1), 29-40.

[3] Boylan, H. (2009). Targeted intervention for developmental education students (T.I.D.E.S.). Journal of Developmental Education, 32(3), 14-23.

[4] Bennui. (2009). Study on First-Year Students Perceptions Concerning Causes of Their Poor Performance in the English II Course.

[5] Piras. (1998). Experimental study of the effectiveness of using printed text as a learner support strategy in the teaching of listening comprehension. Unpublished M.A. (Linguistics) Thesis. Mahidol, Bangkok.

[6] Richard E. Petty, John T. Cacioppo \&David Schumann. (1983). Central and Peripheral Routes to Advertising Effectiveness: The Moderating Role of Involvement. Journal of Consumer Research, Volume 10, Issue 2, Pages 135-146, https://doi.org/10.1086/208954.

[7] Misati. (2009). Skills and strategies: Towards a new methodology for listening. ELT Journal.52 (2) 110-118.

[8] Budden. (2003). Problems in teaching English listening of teachers in government secondary schools in Chon Buri. Unpublished M.A.T. (Teaching of English) Thesis. University of Bangkok.

[9] Gregogy L. Murphy. (2002). The Big Book of Concepts. Cambridge: MIT Press

[10] Abbott, Lauter, \& Dalton. (2007). Inclusion of students with limited English proficiency in NAEP: Classification and measurement issues. Retrieved November 30, 2005, from http://www.nagb.org/pubs/conferences/abedi.doc.

[11] Haneda. (2006). Listening. Oxford: Oxford University Press.

[12] Hanuskek, Eri A, John F Kain \& Steven G Rivkin. (1999). Do higher salaries buy better teachers?, Technical report, National bureau of economic research.

[13] G. Barbieri, Claudio Rossetti \& Paolo Sestio. (2017). Teacher motivation and student learning .April 2017 Politica Economica 33(1):59-72,DOI:10.1429/86376

[14] Howley, C., Strange, M., \& Bickel, R. (2000). Research about school size and school performance in impoverished communities. Washington, DC: Office of Educational Research and Improvement.

[15] W. Harbison \& Eric A. Hanushek. (1992). Educational Performance of the Poor: Lessons from Rural Northeast Brazil.

[16] Husen. (2001). Teaching the spoken language. Cambridge: Cambridge University Press.

[17] Horwitz, E. K. (2001). Language anxiety and achievement, Annual review of applied linguistics. v21 p112-26.

[18] Komenský, J. (2008). English instruction problems of undergraduate English major students in the faculty of education of closed universities in Bangkok metropolis. Unpublished Thesis Kasetsart University.

Fengyi Ma was born in Guangxi, China in 1970.She received her Ed.D degree in education from Tarlac State University, Philippines in 2020.

She is currently an associate professor in the Office of Foreign Languages, Guilin Medical University, Guilin, China. Her research interests include education and English. 